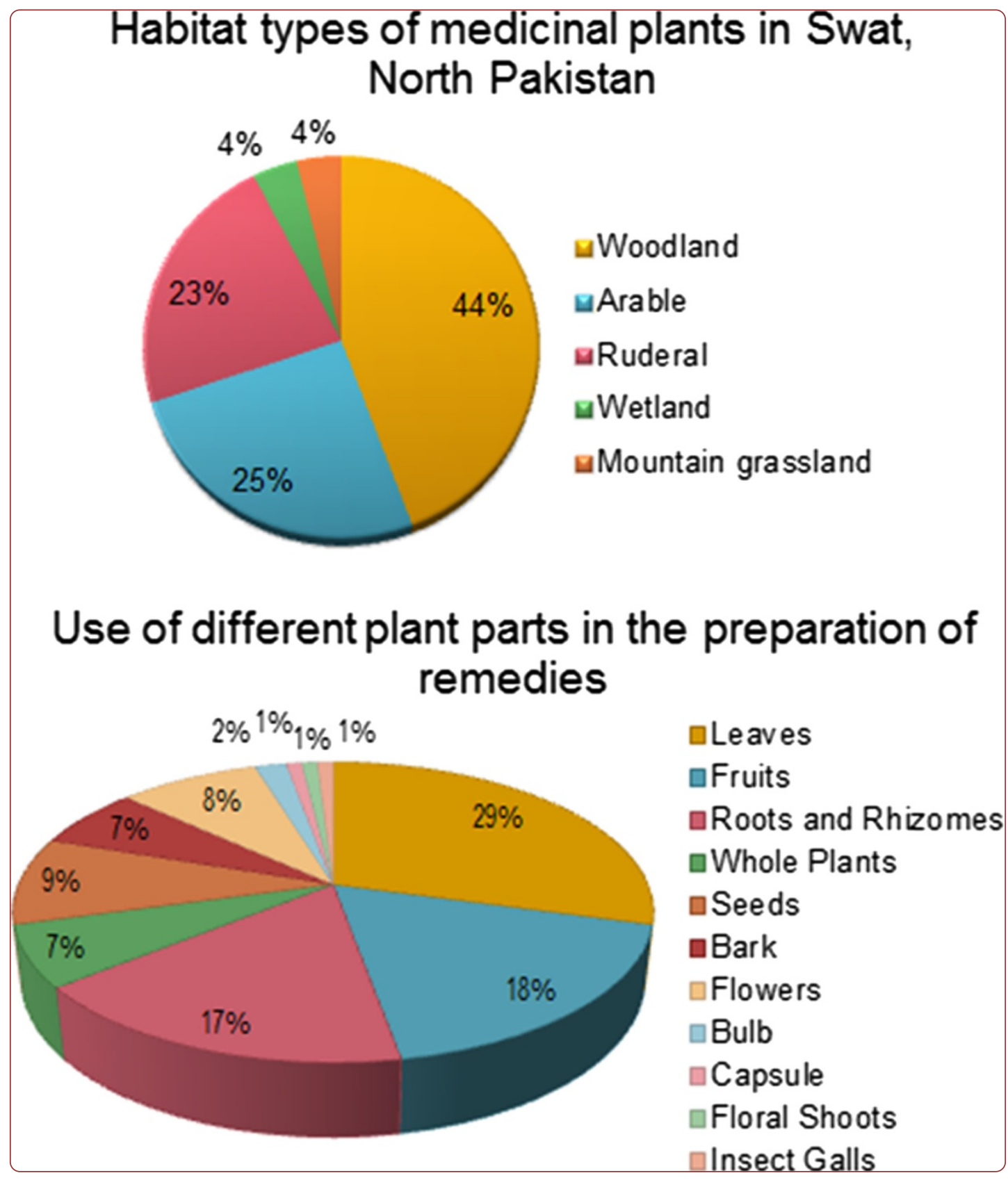

\title{
Diversity and use of ethno-medicinal plants in the region of Swat, North Pakistan
}

Akhtar et al. 


\title{
Diversity and use of ethno-medicinal plants in the region of Swat, North Pakistan
}

\author{
Naveed Akhtar ${ }^{1,2}$, Abdur Rashid $^{3}$, Waheed Murad ${ }^{4}$ and Erwin Bergmeier ${ }^{2 *}$
}

\begin{abstract}
Background: Due to its diverse geographical and habitat conditions, northern Pakistan harbors a wealth of medicinal plants. The plants and their traditional use are part of the natural and cultural heritage of the region. This study was carried out to document which medicinal plant species and which plant parts are used in the region of Swat, which syndrome categories are particularly concerned, and which habitat spectrum is frequented by collectors. Finally, we assessed to which extent medicinal plants are vulnerable due to collection and habitat destruction.

Methods: An ethnobotanical survey was undertaken in the Miandam area of Swat, North Pakistan. Data were collected through field assessment as well as from traditional healers and locals by means of personal interviews and semi-structured questionnaires.

Results: A total of 106 ethno-medicinal plant species belonging to 54 plant families were recorded. The most common growth forms were perennial (43\%) and short-lived herbs (23\%), shrubs (16\%), and trees (15\%). Most frequently used plant parts were leaves (24\%), fruits (18\%) and subterranean parts (15\%). A considerable proportion of the ethno-medicinal plant species and remedies concerns gastro-intestinal disorders. The remedies were mostly prepared in the form of decoction or powder and were mainly taken orally. Eighty out of 106 ethno-medicinal plants were indigenous. Almost 50\% of the plants occurred in synanthropic vegetation while slightly more than $50 \%$ were found in semi-natural, though extensively grazed, woodland and grassland vegetation. Three species (Aconitum violaceum, Colchicum luteum, Jasminum humile) must be considered vulnerable due to excessive collection. Woodlands are the main source for non-synanthropic indigenous medicinal plants. The latter include many range-restricted taxa and plants of which rhizomes and other subterranean parts are dug out for further processing as medicine.
\end{abstract}

Conclusion: Medicinal plants are still widely used for treatment in the area of Swat. Some species of woodlands seem to be adapted to wood-pasture, but vulnerable to overcollecting, and in particular to deforestation. It is suggested to implement local small-scaled agroforestry systems to cultivate vulnerable and commercially valuable ethno-medicinal woodland plants under local self-government responsibility.

Keywords: Ecosystem services, Ethnobotany, Medicinal plants, Miandam, Phytomedicine, Plant applications, Plant conservation, Vernacular plant names

\footnotetext{
*Correspondence: erwin.bergmeier@bio.uni-goettingen.de

${ }^{2}$ Department of Vegetation Analysis and Phytodiversity, Albrecht von Haller Institute of Plant Sciences, Georg August University, Göttingen 37073,

Germany

Full list of author information is available at the end of the article
}

\section{Biomed Central}

(c) 2013 Akhtar et al.; licensee BioMed Central Ltd. This is an Open Access article distributed under the terms of the Creative Commons Attribution License (http://creativecommons.org/licenses/by/2.0), which permits unrestricted use, distribution, and reproduction in any medium, provided the original work is properly cited. 


\section{Introduction}

Plants are an important source of traditional medicine for the treatment of various diseases [1]. It has been estimated that herbal medicines are used by more than $80 \%$ of the world's population in developing countries to meet their primary healthcare needs [2]. In Pakistan, the available modern healthcare services are either insufficient or inaccessible and unaffordable to the majority of people. In addition, due to illiteracy and poverty most of the population is dependent on traditional phytomedicine to cure various ailments. As the country has diverse socioeconomic, ethnic, linguistic and cultural areas, as well as unique biodiversity, copious knowledge of indigenous medicinal plants and their use in treating human ailments might reasonably be expected. More than $10 \%$ of the national flora of Pakistan (600-700 plant species) are used for medicinal purposes [3]. Phytomedicinal research in Pakistan is a recent activity and the documentation of ethnomedicinal plant knowledge and its applications are ongoing [3-6]. The loss of precious medicinal plant wealth due to overgrazing, agricultural expansion, environmental degradation, acculturation and deforestation, enhanced by population pressure and poverty, has been reported by various researchers [3,7-10] but information on which medicinal plant species in particular are vulnerable, and why, is lacking.

Traditional resources of medicinal plants from Chitral, North Pakistan, have been evaluated $[7,11]$. Several studies exist on the ethnomedicinal use of plants in different regions of Swat, North Pakistan [8,12-15]. In an ethnomedicinal study from the valley of Miandam, Swat, a total of 179 plant species have been listed [16], with medicinal use reported for 27 plants, but without reference to local names, habitats, and which parts of these plants are used. Recording the indigenous knowledge of medicinal plants is an urgent task. Traditional knowledge is usually passed verbally from generation to generation, and valuable information about medicinal plants is easily lost if not preserved in written form. The main objective of the present study was therefore to survey and to document the scattered indigenous knowledge of medicinal plants of the Miandam valley as basis for future phytochemical and pharmacological studies. Moreover, and for the first time in any region of Pakistan, the medicinal plants of the study area are classified according to biological and distributional properties as well as ecological preference. It is essential to know where and in which habitats ethno-medicinal plants occur, as such knowledge is a prerequisite to identify vulnerable plant species susceptible to collecting or habitat change.

\section{Study area}

The valley of Miandam, Swat, is a well-known summer resort in northern Pakistan. Located about $50 \mathrm{~km}$ northeast of Saidu Sharif, the valley lies between $35^{\circ} 4^{\prime} \mathrm{N}$ and $72^{\circ}$ 29-32' $\mathrm{E}$ in the mountain range of Hindu Raj [17]. The study area ranges between 1400 to $3900 \mathrm{~m}$ a.s.l. It is a narrow valley with a number of gorges, bounded on the north, east and south by high mountains. Its western boundary is the river Swat. Gujars (Indian Aryans) and Yousafzai (Pakhtoon) are the two main tribes residing in the area. Their main source of income is agriculture (nearly 41\%) [18] and most of the population of the study area is directly or indirectly engaged in it. Miandam is a mountainous region and the cultivated land is insufficient for subsistence. Additional sources of income are daily wages and salaries (20\%), foreign and domestic remittances $(17 \%)$, forest products including medicinal plants (12\%) and other professions (10\%). Findings from [19] reveal that $59 \%$ of the households in north-western Pakistan derive their income from the forests.

Due to its considerable variation in altitude, temperature, topography, soil type and moisture, the vegetation of Miandam Valley can be classified into a series of altitudinal belts, namely dominated by Olea ferruginea and Quercus oblongata (submontane), Pinus wallichiana, Abies pindrow, Picea smithiana and Quercus semecarpifolia (montane), and alpine-subalpine flora, respectively [16]. See also the vegeation maps of the northern Pakistan regions of Chitral and Hunza $[20,21]$.

\section{Methods}

Regular field surveys were carried out in the Miandam valley from September 2010 through July 2011 in order to document the habitats and indigenous uses of ethnomedicinal plants of the valley. The surveys were carried out at different seasons so as to obtain identifiable plants and multiple information and also to cross-check the information provided by the local informants during earlier visits. We interviewed a small group of chiefly elder people of both Gujars and Yousufzai tribes who were highly esteemed in their societies due to their sound knowledge of medicinal plants. Structured questionnaires, formal and informal interviews and participatory observations were used to inquire about vernacular names, used plant parts and the process of remedy preparation. We did not encounter controversial issues among the informants but commonly received complementary information. Moreover, for each plant species growth forms (tree, shrub, woody climber, perennial herb, annual or biennial herb), plant status (indigenous, established alien, cultivated), abundance in the area (common, scattered, rare) and habitat preferences (arable fields, ruderal sites, wetland, woodland, mountain grassland) were recorded. Voucher specimens were identified using relevant standard literature [22-25] and submitted to the Herbarium PUP at the Department of Botany, University of Peshawar. Plant nomenclature was updated using the World Checklist of 
Table 1 Medicinal plants of the Miandam area with their medicinal properties, and biological, ecological and chorological characteristics

\begin{tabular}{|c|c|c|c|c|c|c|c|c|}
\hline Plant family & Taxon name & Local name & Parts used & Medicinal uses, remedies & Growth form & Plant status & Frequency & Habitat \\
\hline Amaranthaceae & Amaranthus viridis & Chalvaray & Leaves & $\begin{array}{l}\text { Leaf extract is emollient, also used } \\
\text { for curing cough and asthma. }\end{array}$ & Annual & Indigenous & Common & Ruderal \\
\hline Anacardiaceae & Pistacia chinensis & Shnai & $\begin{array}{l}\text { Insect galls, leaves and } \\
\text { bark }\end{array}$ & $\begin{array}{l}\text { Powdered insect galls, bark and } \\
\text { leaves are topical antiseptic, also for } \\
\text { curing jaundice and liver diseases. }\end{array}$ & Tree & $\begin{array}{l}\text { Established } \\
\text { alien }\end{array}$ & Scattered & Woodland \\
\hline Apiaceae & Bupleurum longicaule & Gillo & Whole plant & $\begin{array}{l}\text { Powdered plant is mixed with milk } \\
\text { and used as laxative }\end{array}$ & Perennial & Indigenous & Common & Woodland \\
\hline Apiaceae & Coriandrum sativum & Dhanyal & Whole plant & Stimulant and carminative & Annual & Cultivated & Common & Arable \\
\hline Apiaceae & Foeniculum vulgare & Kaga vanalay & Fruit & $\begin{array}{l}\text { Powdered fruit is mixed with sugar, } \\
\text { taken with a cup of milk for curing } \\
\text { urinary problems (dysuria); dry fruits } \\
\text { are carminative and laxative }\end{array}$ & Annual & Cultivated & Common & Arable \\
\hline Apiaceae & Pimpinella diversifolia & Watani kaga & Fruit & Powdered fruits are carminative & Perennial & Indigenous & Scattered & Woodland \\
\hline Apiaceae & Heracleum candicans & Kadu panra & Root & $\begin{array}{l}\text { Decoction of root against colic and } \\
\text { asthma }\end{array}$ & Perennial & Indigenous & Scattered & Wetland \\
\hline Araceae & Arisaema jacquemontii & Marjarai & Rhizome & $\begin{array}{l}\text { Rhizome bolus is given orally to } \\
\text { livestock for respiratory problems }\end{array}$ & Perennial & Indigenous & Scattered & Woodland \\
\hline Araliaceae & Hedera nepalensis & Prewata & Leaves & $\begin{array}{l}\text { Juice from leaves for curing diabetes, } \\
\text { also considered as blood purifier }\end{array}$ & Woody climber & Indigenous & Common & Woodland \\
\hline Asclepiadaceae & Periploca aphylla & Barara & Stem, fruits & $\begin{array}{l}\text { Milky juice of stem and fruit applied } \\
\text { to swellings; stem latex as } \\
\text { antimycotic for curing dermatitis in } \\
\text { livestock }\end{array}$ & Shrub & Indigenous & Common & Ruderal \\
\hline Asteraceae & Artemisia scoparia & Jaukay & Shoot and seeds & $\begin{array}{l}\text { Respiratory stimulant, anthelmintic, } \\
\text { purgative and against earache }\end{array}$ & Biennial & Indigenous & Common & Woodland \\
\hline Asteraceae & Cichorium intybus & Han & Root & $\begin{array}{l}\text { Decoction of fresh root for treatment } \\
\text { of fever }\end{array}$ & Perennial & Indigenous & Common & Ruderal \\
\hline Asteraceae & Echinops echinatus & $\begin{array}{l}\text { Ghwand Saray } \\
\text { Ghanowala }\end{array}$ & Root & $\begin{array}{l}\text { Powdered root applied to wounds of } \\
\text { cattle for killing maggots; also to kill } \\
\text { lice }\end{array}$ & Perennial & Indigenous & Scattered & Wetland \\
\hline Asteraceae & Launaea procumbens & Shauda pai & Leaves & $\begin{array}{l}\text { Mixture of powdered leaves with } \\
\text { sugar to enhance lactation in } \\
\text { livestock }\end{array}$ & Perennial & Indigenous & Common & Ruderal \\
\hline Asteraceae & Sonchus asper & Shauda pai & Shoot & $\begin{array}{l}\text { Shoots fed to livestock for } \\
\text { enhancing lactation }\end{array}$ & Annual & Indigenous & Common & Ruderal \\
\hline Asteraceae & Taraxacum sp. & Ziar gulai & Leaves and roots & $\begin{array}{l}\text { Grinded leaves are tonic, root } \\
\text { decoction against kidney and liver } \\
\text { disorders }\end{array}$ & Perennial & Indigenous & Common & Ruderal \\
\hline Asteraceae & Xanthium strumarium & Ghishkay & Leaves & $\begin{array}{l}\text { Leaf decoction recommended in } \\
\text { malarial fever }\end{array}$ & Annual & Indigenous & Common & Ruderal \\
\hline
\end{tabular}


Table 1 Medicinal plants of the Miandam area with their medicinal properties, and biological, ecological and chorological characteristics (Continued)

\begin{tabular}{|c|c|c|c|c|c|c|c|c|}
\hline Berberidaceae & Berberis lycium & Kwaray & Root bark & $\begin{array}{l}\text { Dried root bark given orally as body } \\
\text { tonic }\end{array}$ & Shrub & Indigenous & Scattered & Woodland \\
\hline Berberidaceae & $\begin{array}{l}\text { Podophyllum } \\
\text { hexandrum }\end{array}$ & Kakora & Rhizome & $\begin{array}{l}\text { Powdered rhizome used to cure liver } \\
\text { diseases }\end{array}$ & Perennial & Indigenous & Scattered & Woodland \\
\hline Boraginaceae & $\begin{array}{l}\text { Cynoglossum } \\
\text { lanceolatum }\end{array}$ & Gat gul & Whole plant & $\begin{array}{l}\text { Powdered plant taken with a } \\
\text { decoction of Coriandrum sativum } \\
\text { fruits as laxative }\end{array}$ & Perennial & Indigenous & Common & Woodland \\
\hline Boraginaceae & Onosma hispida & Khwaga abai & Root & $\begin{array}{l}\text { Used to color mustard oil which is } \\
\text { applied for smoothing hair }\end{array}$ & Perennial & Indigenous & Common & Ruderal \\
\hline Brassicaceae & Brassica campestris & Sharshum & Seeds & $\begin{array}{l}\text { Oil, extracted from seeds, is used as } \\
\text { ointment, for massage of body and } \\
\text { hair }\end{array}$ & Annual & Cultivated & Common & Arable \\
\hline Brassicaceae & $\begin{array}{l}\text { Brassica campestris var. } \\
\text { rapa }\end{array}$ & Tepar & Leaves, roots & $\begin{array}{l}\text { Against stomachache and ulcer } \\
\text { problems }\end{array}$ & Annual & Cultivated & Common & Arable \\
\hline Brassicaceae & Capsella bursa-pastoris & Bambesa & Leaves and seeds & $\begin{array}{l}\text { Paste of fresh leaves with milk for } \\
\text { curing diarrhea; seeds are stimulant } \\
\text { and diuretic }\end{array}$ & Annual & Indigenous & Common & Ruderal \\
\hline Brassicaceae & Nasturtium officinale & Talmera & Young shoot & $\begin{array}{l}\text { Young shoot against constipation } \\
\text { and stomachache }\end{array}$ & Perennial & Indigenous & Common & Wetland \\
\hline Buxaceae & Sarcococca saligna & Ladanr & Leaves & $\begin{array}{l}\text { Heated in mustard oil and applied to } \\
\text { muscular pain; infusion of leaves } \\
\text { orally for rheumatism }\end{array}$ & Perennial & Indigenous & Common & Woodland \\
\hline Cannabaceae & Cannabis sativa & Bang & Leaves & $\begin{array}{l}\text { Leaves in bandage for wound } \\
\text { healing; powdered leaves as } \\
\text { anodyne, sedative, tonic and } \\
\text { narcotic; juice added with milk and } \\
\text { nuts as a cold drink ("Tandai") } \\
\text { generating a pleasant excitement; } \\
\text { "Charas" is also prepared from it }\end{array}$ & Annual & Indigenous & Common & Arable \\
\hline Caprifoliaceae & Sambucus wightiana & Benakai & $\begin{array}{l}\text { Leaves, fruits and } \\
\text { flowers }\end{array}$ & $\begin{array}{l}\text { Poultice from leaves and flowers to } \\
\text { treat burns and rheumatism; berries } \\
\text { are purgative and used in dropsy }\end{array}$ & Shrub & Indigenous & Rare & Woodland \\
\hline Caprifoliaceae & Viburnum grandiflorum & Ghuz meva & fruit & $\begin{array}{l}\text { Fresh fruit is eaten to cure stomach } \\
\text { problems }\end{array}$ & Shrub & Indigenous & Common & Woodland \\
\hline Caryophyllaceae & Arenaria griffithii & Kinar & Shoots & $\begin{array}{l}\text { Dried shoot powder with honey } \\
\text { after meal as antispasmodic }\end{array}$ & Perennial & Indigenous & Common & Woodland \\
\hline Caryophyllaceae & Silene vulgaris & Matorangay & Shoot & $\begin{array}{l}\text { Shoot against stomachache and as } \\
\text { emollient }\end{array}$ & Perennial & Indigenous & Common & Woodland \\
\hline Caryophyllaceae & Stellaria media & Oulalai & Whole plant & Decoction is considered as purgative & Annual & Indigenous & Common & Arable \\
\hline Chenopodiaceae & Chenopodium album & Sarmay & Whole plant & $\begin{array}{l}\text { Dried powdered plant considered as } \\
\text { carminative and diuretic agent }\end{array}$ & Annual & Indigenous & Common & Ruderal \\
\hline Clusiaceae & Hypericum perforatum & Shin chai & Shoot & $\begin{array}{l}\text { Used as diuretic and its tea is } \\
\text { stimulant and analgesic }\end{array}$ & Perennial & Indigenous & Scattered & Woodland \\
\hline
\end{tabular}

Used as diuretic and its tea is 
Table 1 Medicinal plants of the Miandam area with their medicinal properties, and biological, ecological and chorological characteristics (Continued)

\begin{tabular}{|c|c|c|c|c|c|c|c|c|}
\hline Convolvulaceae & Convolvulus arvensis & Prewatai & Whole plant & $\begin{array}{l}\text { Purgative, also applied in skin } \\
\text { disorders }\end{array}$ & $\begin{array}{l}\text { Perennial, } \\
\text { climber }\end{array}$ & Indigenous & Common & Arable \\
\hline Cuscutaceae & Cuscuta reflexa & Zelai & Whole plant & $\begin{array}{l}\text { Decoction for urine control, diabetes } \\
\text { and blood purification; plant extract } \\
\text { used as anti-lice }\end{array}$ & $\begin{array}{l}\text { Perennial, } \\
\text { climber }\end{array}$ & $\begin{array}{l}\text { Established } \\
\text { alien }\end{array}$ & Scattered & Arable \\
\hline Dioscoreaceae & Dioscorea deltoidea & Kanis zelai & Rhizome & $\begin{array}{l}\text { Powdered rhizome mixed with } \\
\text { powdered root of Berberis lycium, the } \\
\text { mixture is used for treatment of } \\
\text { jaundice and ulcers }\end{array}$ & $\begin{array}{l}\text { Perennial, } \\
\text { climber }\end{array}$ & Indigenous & Scattered & Woodland \\
\hline Ebenaceae & Diospyros kaki & Sur amlok & Ripe fruits & Laxative & Tree & Cultivated & Common & Arable \\
\hline Ebenaceae & Diospyros lotus & Tour amlok & Dried ripe fruits & $\begin{array}{l}\text { Carminative, purgative and causing } \\
\text { flatulence; boiled in milk and taken } \\
\text { against constipation and dysentery }\end{array}$ & Tree & Cultivated & Common & Arable \\
\hline Elaeagnaceae & Elaeagnus umbellata & Ghanum ranga & Flowers, leaves & $\begin{array}{l}\text { Decoction of flowers used twice a } \\
\text { day to cure heart diseases; decoction } \\
\text { of leaves against cough; mature raw } \\
\text { seeds eaten as vitamin C source }\end{array}$ & Shrub & Indigenous & Rare & Woodland \\
\hline Euphorbiaceae & Euphorbia wallichii & Shangla & Whole plant & $\begin{array}{l}\text { Dried leaves and seeds given to } \\
\text { children in bowel complains; plant } \\
\text { juice against ringworm }\end{array}$ & Perennial & Indigenous & Common & Woodland \\
\hline Euphorbiaceae & Ricinus communis & Harhanda & Seeds & $\begin{array}{l}\text { Seed oil demulcent and to evacuate } \\
\text { bowels in children }\end{array}$ & Shrub & $\begin{array}{l}\text { Established } \\
\text { alien }\end{array}$ & Scattered & Ruderal \\
\hline Fabaceae & Indigofera heterantha & Ghwarija & Root and leaves & $\begin{array}{l}\text { Dried powdered root taken with } \\
\text { glass of water against scabies; leaves } \\
\text { against stomach problems }\end{array}$ & Shrub & Indigenous & Common & Woodland \\
\hline Fabaceae & Lathyrus aphaca & Korkamanai & Seed & $\begin{array}{l}\text { Decoction of the seed } 3 \text { times a day } \\
\text { for wound healing }\end{array}$ & Annual & Indigenous & Scattered & Arable \\
\hline Fabaceae & Lotus corniculatus & Fateh khana & Whole plant & $\begin{array}{l}\text { Decoction of dried powdered plant } \\
\text { with ghee or boiled water against } \\
\text { sexual debility and backache }\end{array}$ & Perennial & Indigenous & Scattered & Woodland \\
\hline Fagaceae & Quercus oblongata & Banj & Fruit & Powdered fruits in urinary infection & Tree & Indigenous & Common & Woodland \\
\hline Fagaceae & Quercus floribunda & Tour banj & Fruit & $\begin{array}{l}\text { Powdered fruits for treating } \\
\text { gonorrhea and urinary disease }\end{array}$ & Tree & Indigenous & Common & Woodland \\
\hline Fumariaceae & Corydalis stewartii & Mamera & Floral shoot & $\begin{array}{l}\text { Decoction of floral shoot to cure eye } \\
\text { diseases }\end{array}$ & Biennial & Indigenous & Scattered & $\begin{array}{l}\text { Mountain } \\
\text { grassland }\end{array}$ \\
\hline Geraniaceae & Geranium wallichianum & Srazela & Root & $\begin{array}{l}\text { Root decoction with pods of Pistacia } \\
\text { chinensis to treat cough and fever } \\
\text { and urinary complaints }\end{array}$ & Perennial & Indigenous & Common & woodland \\
\hline Hippocastanaceae & Aesculus indica & Jawaz & Seeds and bark & $\begin{array}{l}\text { Fruits are anthelmintic and given to } \\
\text { horses in colic; plant oil externally } \\
\text { used against rheumatism; nuts against } \\
\text { colic and to cure chest diseases in } \\
\text { horses, donkeys and mules }\end{array}$ & Tree & Indigenous & Scattered & Woodland \\
\hline
\end{tabular}


Table 1 Medicinal plants of the Miandam area with their medicinal properties, and biological, ecological and chorological characteristics (Continued)

\begin{tabular}{|c|c|c|c|c|c|c|c|c|}
\hline Juglandaceae & Juglans regia & Ghwaz & Fruit, bark, leaves & $\begin{array}{l}\text { Dried fruit mixed with coconut and } \\
\text { honey used as tonic; bark (locally } \\
\text { called Dandasa) for cleaning and } \\
\text { sparkling of teeth; decoction of } \\
\text { leaves against eczema and intestinal } \\
\text { worms }\end{array}$ & Tree & Cultivated & Common & Arable \\
\hline Lamiaceae & Ajuga bracteosa & Booti & Whole plant & $\begin{array}{l}\text { Locally, decoction of the plant or its } \\
\text { powder swallowed with water } \\
\text { before breakfast for the treatment of } \\
\text { throat sore, internal colic, purifying } \\
\text { blood and epilepsy; decoction for } \\
\text { curing jaundice and hypertension }\end{array}$ & Perennial & Indigenous & Common & Ruderal \\
\hline Lamiaceae & Mentha spicata & Podina & Leaves and stem & Carminative & Perennial & Cultivated & Common & Arable \\
\hline Lamiaceae & Mentha royleana & Valenay & whole plant & $\begin{array}{l}\text { Decoction of leaves for treatment of } \\
\text { diarrhea in children; powdered plant } \\
\text { mixed with sugar for prevention of } \\
\text { vomiting and dyspepsia }\end{array}$ & Perennial & Indigenous & Common & Ruderal \\
\hline Lamiaceae & Nepeta cataria & Pisho botai & Flowers and leaves & $\begin{array}{l}\text { Dried leaves and flowering tops } \\
\text { carminative }\end{array}$ & Perennial & Indigenous & Scattered & $\begin{array}{l}\text { Mountain } \\
\text { grassland }\end{array}$ \\
\hline Lamiaceae & Otostegia limbata & Spin azghai & Whole plant & $\begin{array}{l}\text { Juice of leaves applied to gums for } \\
\text { treatment of gum problem in } \\
\text { children; dried powder of plant is } \\
\text { used in jaundice }\end{array}$ & Perennial & Indigenous & Common & Woodland \\
\hline Lamiaceae & Isodon rugosus & Spearkai & Leaves & $\begin{array}{l}\text { Dried leaves put in mouth as } \\
\text { remedy for toothache }\end{array}$ & Shrub & Indigenous & Common & Woodland \\
\hline Lamiaceae & Origanum vulgare & Shamakay & Whole plant & $\begin{array}{l}\text { Diuretic and against toothache and } \\
\text { earache }\end{array}$ & Perennial & Indigenous & Common & Woodland \\
\hline Lamiaceae & Salvia lanata & Spera botai & Leaves & $\begin{array}{l}\text { Paste of leaves applied to toes } \\
\text { laceration in hot and moist season }\end{array}$ & Perennial & Indigenous & Scattered & Woodland \\
\hline Lamiaceae & Salvia moorcroftiana & Kherghwag & Leaves & $\begin{array}{l}\text { Brassica campestris oil applied to } \\
\text { fresh leaves tied round for healing of } \\
\text { wounds }\end{array}$ & Perennial & Indigenous & Common & Ruderal \\
\hline Lamiaceae & Thymus linearis & Chi botai & Shoots & $\begin{array}{l}\text { Tea of shoots advised for treating } \\
\text { pain and fever }\end{array}$ & Perennial & Indigenous & Common & $\begin{array}{l}\text { Mountain } \\
\text { grassland }\end{array}$ \\
\hline Liliaceae & Allium sativum & Ouga & Bulb and leaves & $\begin{array}{l}\text { Boiled and the cooled extract } \\
\text { administered against diarrhea, } \\
\text { dysentery and for lowering blood } \\
\text { pressure; bulbs stimulant; leaves } \\
\text { diuretic, aphrodisiac and } \\
\text { expectorant; antiseptic; juice applied } \\
\text { to soothe irritation caused by } \\
\text { scorpion and hornet stings }\end{array}$ & Perennial & Cultivated & Common & Arable \\
\hline
\end{tabular}


Table 1 Medicinal plants of the Miandam area with their medicinal properties, and biological, ecological and chorological characteristics (Continued)

\begin{tabular}{|c|c|c|c|c|c|c|c|c|}
\hline Liliaceae & Allium cepa & Piaz & Bulb and leaves & $\begin{array}{l}\text { Bulbs stimulant; leaves diuretic, } \\
\text { aphrodisiac and expectorant; also } \\
\text { antiseptic and juice applied to } \\
\text { soothe irritation caused by scorpion } \\
\text { and hornet sting; Mountaineers have } \\
\text { it with them while crossing high } \\
\text { altitude passes as it enhances the } \\
\text { intake of oxygen }\end{array}$ & Perennial & Cultivated & Common & Arable \\
\hline Liliaceae & Colchicum luteum & Qaimat guallay & Whole plant & $\begin{array}{l}\text { Blood purifier, laxative and } \\
\text { aphrodisiac; fried corms are used for } \\
\text { joints pain }\end{array}$ & Perennial & Indigenous & Rare & $\begin{array}{l}\text { Mountain } \\
\text { grassland }\end{array}$ \\
\hline Liliaceae & $\begin{array}{l}\text { Polygonatum } \\
\text { multiflorum }\end{array}$ & Noorealam & Rhizome & $\begin{array}{l}\text { Rhizome infusion against dysentery; } \\
\text { referred aphrodisiac }\end{array}$ & Perennial & Indigenous & Scattered & Woodland \\
\hline Liliaceae & $\begin{array}{l}\text { Polygonatum } \\
\text { verticillatum }\end{array}$ & Noorealam & Rhizome & $\begin{array}{l}\text { Against rheumatism and as } \\
\text { aphrodisiac }\end{array}$ & Perennial & Indigenous & Scattered & Woodland \\
\hline Malvaceae & Abelmoschus esculentus & Bhindi & Fruits & Emollient, demulcent and diuretic & Annual & Cultivated & Scattered & Arable \\
\hline Meliaceae & Melia azedarach & Tora bakyana, shandai & $\begin{array}{l}\text { Fruits, shoots, bark, } \\
\text { leaves }\end{array}$ & $\begin{array}{l}\text { Dried, crushed fruits against gastric } \\
\text { trouble, fever and cough; dry leaves } \\
\text { mixed with wheat flour used as } \\
\text { anthelmintic in livestock; decoction } \\
\text { of the bark considered anti-allergic; } \\
\text { extraction of leaves used by women } \\
\text { against head lice; leaves, young } \\
\text { branches or fermented fruits are } \\
\text { given as carminative to cattle, when } \\
\text { belly is swollen through gas } \\
\text { accumulation due to overeating }\end{array}$ & Tree & $\begin{array}{l}\text { Established } \\
\text { alien }\end{array}$ & Scattered & Woodland \\
\hline Moraceae & Ficus palmata & Inzer & Flowers and fruits & $\begin{array}{l}\text { Fresh floral parts as demulcent; juice } \\
\text { extracted from fruit as expectorant }\end{array}$ & Tree & Cultivated & Common & Arable \\
\hline Moraceae & Morus alba & Toot & Fruit & Fruit to treat constipation and cough & Tree & Indigenous & Common & Arable \\
\hline Oleaceae & Jasminum humile & Rambil chambil & Roots and flowers & $\begin{array}{l}\text { Powdered roots as anthelmintic and } \\
\text { diuretic; juice extracted from flowers } \\
\text { against skin diseases, headache and } \\
\text { mouth rash }\end{array}$ & Shrub & Indigenous & Rare & Woodland \\
\hline Oleaceae & Olea europaea & Khona & Leaves & $\begin{array}{l}\text { Decoction of leaves as gargle } \\
\text { considered as remedy for toothache, } \\
\text { mouth and gum diseases }\end{array}$ & Tree & Cultivated & Scattered & Arable \\
\hline Oxalidaceae & Oxalis corniculata & Tarukey & Whole plant & $\begin{array}{l}\text { Decoction of plant to enhance } \\
\text { digestion }\end{array}$ & Annual & Indigenous & Common & Ruderal \\
\hline Paeoniaceae & Paeonia emodi & Mamekh & Rhizome & $\begin{array}{l}\text { Powdered rhizome with milk to cure } \\
\text { backache and general weakness }\end{array}$ & Perennial & Indigenous & Scattered & Woodland \\
\hline Papaveraceae & Papaver somniferum & Qashqash & Capsule, seeds & $\begin{array}{l}\text { Capsules and seeds as narcotic; dried } \\
\text { capsule to make tea for cough and }\end{array}$ & Annual & Indigenous & Scattered & Arable \\
\hline
\end{tabular}


Table 1 Medicinal plants of the Miandam area with their medicinal properties, and biological, ecological and chorological characteristics (Continued)

\begin{tabular}{|c|c|c|c|c|c|c|c|c|}
\hline Plantaginaceae & Plantago lanceolata & Jabai & Leaves & $\begin{array}{l}\text { Leaves applied to treat bedsores, } \\
\text { inflamed surfaces and candidiasis }\end{array}$ & Perennial & Indigenous & Scattered & Ruderal \\
\hline Plantaginaceae & Plantago major & Ghwa jabai & Seeds, leaves & $\begin{array}{l}\text { Leaves applied to treat bedsores and } \\
\text { candidiasis }\end{array}$ & Perennial & Indigenous & Scattered & Ruderal \\
\hline Platanaceae & Platanus orientalis & Chinar & Bark & $\begin{array}{l}\text { Powdered bark taken orally to } \\
\text { control diarrhea }\end{array}$ & Tree & Indigenous & Scattered & Woodland \\
\hline Poaceae & Avena sativa & Jamdaray & Fruit & $\begin{array}{l}\text { Fried in ghee and milk, the paste is } \\
\text { considered as general body tonic } \\
\text { and aphrodisiac }\end{array}$ & Annual & Cultivated & Common & Arable \\
\hline Poaceae & Cynodon dactylon & Kabal & Whole plant & $\begin{array}{l}\text { Decoction as blood purifier and to } \\
\text { control nose bleed; chewed and } \\
\text { placed on wound to stop bleeding } \\
\text { and as topical anti-septic }\end{array}$ & Perennial & Indigenous & Common & Ruderal \\
\hline Polygonaceae & Rumex dentatus & Shalkhay & Rhizome, leaves & $\begin{array}{l}\text { Rhizome and leaves as poultice for } \\
\text { wound healing }\end{array}$ & Annual & Indigenous & Common & Ruderal \\
\hline Portulacaceae & Portulaca oleracea s.l. & Warkharae & Shoot & $\begin{array}{l}\text { Shoot decoction against liver and } \\
\text { kidney diseases }\end{array}$ & Annual & Cultivated & Common & Arable \\
\hline Primulaceae & Primula denticulata & Mamera & Stem base & $\begin{array}{l}\text { Infusion of young stem base } \\
\text { ophthalmic }\end{array}$ & Perennial & Indigenous & Common & Woodland \\
\hline Punicaceae & Punica granatum & Nangoray, Anar & Fruit & $\begin{array}{l}\text { Dried fruit in bolus form for removal } \\
\text { of intestinal helminths }\end{array}$ & Shrub & Cultivated & Scattered & Arable \\
\hline Ranunculaceae & Aconitum violaceum & $\begin{array}{l}\text { Zaharmora, Da Ghra } \\
\text { Zahar }\end{array}$ & Rhizome & $\begin{array}{l}\text { Rhizomes, wrapped in sheep or goat } \\
\text { intestine and thoroughly boiled in } \\
\text { milk; milk discarded and rhizomes } \\
\text { crushed into powder, taken against } \\
\text { rheumatism and arthritis; } \\
\text { administering as such may cause } \\
\text { death or mental problems if } \\
\text { overdozed }\end{array}$ & Perennial & Indigenous & Rare & Woodland \\
\hline Ranunculaceae & Caltha alba & Makan path & Leaves & Leaves laxative in nature & Perennial & Indigenous & Scattered & Wetland \\
\hline Ranunculaceae & Delphinium denudatum & Jadwar & Rhizome & $\begin{array}{l}\text { Rhizome powder with water to cure } \\
\text { cough and fever }\end{array}$ & Perennial & Indigenous & Scattered & Woodland \\
\hline Rosaceae & Fragaria bucharica & Da zmaki toot & Root, fruit & $\begin{array}{l}\text { Powdered root useful in disease of } \\
\text { urinary tract; fruits carminative and } \\
\text { laxative }\end{array}$ & Perennial & Indigenous & Common & Woodland \\
\hline Rosaceae & Prunus armeniaca & Khubanai & stem & $\begin{array}{l}\text { Gum obtained from stem famed as } \\
\text { anticancer }\end{array}$ & Tree & Cultivated & Common & Arable \\
\hline Rosaceae & Prunus domestica & Alucha & Fruits & Fruit laxative & Tree & Cultivated & Common & Arable \\
\hline Rosaceae & Rosa moschata & Gulab & Flowers & $\begin{array}{l}\text { Decoction of flowers for curing } \\
\text { stomach disorders }\end{array}$ & Shrub & Indigenous & Scattered & Woodland \\
\hline Rosaceae & Spiraea spec. & Krachae & Flowers & Tea from its flowers to ease natal & Shrub & Indigenous & Common & Woodland \\
\hline
\end{tabular}

ea from its flowers to ease natal - Shrub pain 
Table 1 Medicinal plants of the Miandam area with their medicinal properties, and biological, ecological and chorological characteristics (Continued)

\begin{tabular}{|c|c|c|c|c|c|c|c|c|}
\hline Rutaceae & Skimmia laureola & Nazar pana & Leaves & $\begin{array}{l}\text { Burnt incense to expel evils and evil } \\
\text { eyes; tea for indigestion, smoke } \\
\text { considered as antiseptic }\end{array}$ & Shrub & Indigenous & Common & Woodland \\
\hline Rutaceae & Zanthoxylum armatum & Dambara & Fruit & $\begin{array}{l}\text { Fruits as antipyretic and for treating } \\
\text { stomachache }\end{array}$ & Shrub & Indigenous & Scattered & Woodland \\
\hline Saxifragaceae & Bergenia stracheyi & The Spinsar Gat Pana & Rhizome & $\begin{array}{l}\text { Powdered rhizome with milk in the } \\
\text { mornings as tonic }\end{array}$ & Perennial & Indigenous & Common & Woodland \\
\hline Simaroubaceae & Ailanthus altissima & Backyanra & bark & $\begin{array}{l}\text { Bark juice mixed with milk to cure } \\
\text { dysentery and diarrhea }\end{array}$ & Tree & $\begin{array}{l}\text { Established } \\
\text { alien }\end{array}$ & Common & Arable \\
\hline Solanaceae & Atropa acuminata & Bargak & leaves & $\begin{array}{l}\text { Poultice of leaves against pain and } \\
\text { rheumatism }\end{array}$ & Perennial & Indigenous & Scattered & Woodland \\
\hline Solanaceae & Capsicum annuum & Marchakay & Fruits & Carminative & Annual & Cultivated & Common & Arable \\
\hline Solanaceae & Datura stramonium & Batora & $\begin{array}{l}\text { Leaves, seeds and } \\
\text { flowers }\end{array}$ & $\begin{array}{l}\text { poultice of flowers applied to } \\
\text { wounds to reduce pain; seeds } \\
\text { narcotic in nature }\end{array}$ & Annual & Indigenous & Common & Ruderal \\
\hline Solanaceae & Solanum nigrum & Kachmacho & Leaves and fruit & $\begin{array}{l}\text { Leave paste applied to treat skin } \\
\text { inflammation, fruits against fever }\end{array}$ & Annual & Indigenous & Common & Ruderal \\
\hline Solanaceae & Solanum virginianum & Marraghonay & Fruit & $\begin{array}{l}\text { Decoction of fruit diuretic and } \\
\text { anthelmintic }\end{array}$ & Perennial & Indigenous & Scattered & Ruderal \\
\hline Solanaceae & Withania somnifera & Kotilal & Whole plant & Aphrodisiac & Shrub & Indigenous & Scattered & Ruderal \\
\hline Thymelaeaceae & Daphne mucronata & Laighonai & Fruits, leaves & $\begin{array}{l}\text { Poultice from fruits and leaves } \\
\text { against rheumatism }\end{array}$ & Shrub & Indigenous & Common & Woodland \\
\hline Ulmaceae & Celtis australis & Tagha & Fruits, bark & $\begin{array}{l}\text { Fruits against colic and amenorrhea; } \\
\text { bark decoction as anti-allergic }\end{array}$ & Tree & Indigenous & Scattered & Woodland \\
\hline Urticaceae & Debregeasia saeneb & Ajlai & Leaves & $\begin{array}{l}\text { Fresh ground leaves in paste form } \\
\text { for blistered feet }\end{array}$ & Shrub & Indigenous & Common & Woodland \\
\hline Verbinaceae & Verbena officinalis & Shamakai & Whole plant & Decoction is anti-malarial & Perennial & Indigenous & Common & Ruderal \\
\hline
\end{tabular}


Selected Plant Families (http://apps.kew.org/wcsp/home. do) and The Plant List (www.theplantlist.org/). Family assignation in this paper follows the Flora of Pakistan [25].

\section{Results and discussion}

\section{Plant diversity, use and applications}

A total of 106 ethno-medicinal plant species belonging to 96 genera and 54 plant families were recorded. The plants have been used to treat a wide range of diseases from simple headache to complex disorders of kidney and liver. The results are presented in Table 1 with family names in alphabetical order, taxon name, local name, parts used, medicinal use, growth form, plant status, frequency and habitat preference. Perennial herbs were the most common growth form among medicinal plants (43\%), followed by annuals and biennials (23\%), shrubs (16\%) and trees (15\%) As far as documented the use of herbs for remedy preparation in the study area is in consistence with other studies [11,26-40].

Ninety-nine of the species (93\%) are used for human ailments, three species (3\%) for livestock cure and four (4\%) to treat both human and livestock ailments. No less than 44 plant species were used to treat gastro-intestinal disorders such as dyspepsia, dysentery and stomach-ache followed by the treatment of dermatological diseases with more than 25 herbal remedies. Ten species were used against skeleto-muscular complaints like rheumatism, backache and muscular pain. Sixteen species were used to cure respiratory problems such as cough and asthma, fourteen for urinary complaints, twelve for cardio-vascular complaints and circulatory diseases, twelve to treat fever and headache, eleven for genital and sexual diseases, six for dental problems, six for ear, nose, throat (ENT) and eyes diseases, two for nerve disorders, one species (Spiraea spec.) was used to ease childbirth, and eighteen species for other purposes (wounds, cuts, narcotic, tonic, anticancer and tumor) (Table 2). The leaves of Skimmia laureola are used for spiritual purposes.

A single plant species may be used to cure several human ailments (Table 2). Some of the remedies were prepared by combining different plants such as the powdered rhizome of Dioscorea deltoidea mixed with powdered root of Berberis lycium for the treatment of jaundice and ulcers. Similarly, root decoction of Geranium wallichianum with pods of Pistacia chinensis was used for curing urinary complaints, cough and fever. According to traditional healers, complex medicines of two or more plant species are more potent than those prepared with single species. This has been attributed to interactive effects of the plants [41]. The most common medicinal recipe preparation was in powder form followed by decoction, infusion, juices, poultice and paste.

The traditional healers and local herbalists of the region usually utilize every part of the plant. However, the use of a particular plant part depends on the plant habit and user's needs. The most frequently used plant parts in the preparation of herbal remedies were leaves (29\%), followed by fruit (18\%), roots and rhizomes (17\%), and whole plants $(7 \%)$. Seeds (9\%), flowers $(8 \%)$, bark $(7 \%)$, bulbs $(2 \%)$, capsules, floral shoots and insect galls (1\% each) have also been used. The use of specific plant parts suggests that these parts have strongest medicinal properties but it needs biochemical analysis and pharmaceutical screening to cross-check the local information. Our findings of the frequent use of green leaves in the preparation of remedies corroborate the results of [42-46].

Different liquids such as water, juices, sugar, tea, honey, mustard oil, desi ghee (butter) and milk are mixed with plants or plant parts during the preparation of the remedies. The prepared remedies are mostly administered orally (77\%), less frequently dermally (10\%) or both orally and dermally (12\%). Only $1 \%$ is administered through ears or eyes.

\section{Habitats and conservation of ethno-medicinal plants}

Eighty-two out of 106 medicinal plants are indigenous to the area while the others are cultivated (19) or established alien plants (5). The latter groups are of no conservation concern as they are common (17) or scattered (7) in the study area. Also among the indigenous medicinal plants the majority of species is common (59\%) or scattered (35\%) in the area, thus neither of immediate conservation concern. Only five medicinal plant species (6\%) are rare in the study area: Aconitum violaceum, Colchicum luteum, Elaeagnus umbellata, Jasminum humile and Sambucus wightiana. Sambucus and Elaeagnus are woodland shrubs of which leaves and fruits or leaves and flowers, respectively, are collected for medicinal purposes. Since this kind of harvesting is non-destructive, the rarity of the shrub species is apparently not caused by overcollection. In contrast, populations of Aconitum violaceum, Colchicum luteum and Jasminum humile may be harmed since rhizomes, corms or whole plants are collected, respectively. In these cases, plant populations should be monitored to avoid overcollection.

The synanthropic flora (i.e., occurring in arable fields or ruderal sites) contains a high proportion of the ethno-medicinal plants. Slightly under 50\% (51) out of the 106 ethno-medicinal plant species occur in manmade habitats (in arable fields 27 species, most of which being cultivated; another 24 in ruderal sites). Since they can be expected to grow abundantly in or near settlements, or are even cultivated and harvested, they may be collected without much effort, and in suitable quantities. Slightly more than $50 \%$ (55) of the ethno-medicinal plant species encountered in the study area occur in seminatural habitats (though extensively grazed or otherwise used). Most species of the latter group (47) occurred in 
Table 2 List of ethno-medicinal plants applied with different syndromes

\begin{tabular}{ll}
\hline Syndrome category & Plants \\
\hline Gastrointestinal disorders & Aesculus indica, Ailanthus altissima, Ajuga bracteosa, Allium sativum, Artemisia scoparia, \\
& Brassica campestris var. rapa, Bupleurum longicaule, Capsella bursa-pastoris, Caltha alba, \\
Celtis australis, Capsicum annuum, Chenopodium album, Colchicum luteum, Convolvulus & arvensis, Coriandrum sativum, Cynoglossum lanceolatum, Dioscorea deltoidea, Diospyros \\
kaki, Diospyros lotus, Euphorbia wallichii, Foeniculum vulgare, Fragaria bucharica, Heracleum & candicans, Hypericum perforatum, Indigofera heterantha, Jasminum humile, Melia \\
azedarach, Mentha spicata, Mentha royleana, Nasturtium officinale, Nepeta cataria, Oxalis & corniculata, Pimpinella diversifolia, Plantago major, Platanus orientalis, Polygonatum \\
verticillatum, Prunus domestica, Punica granatum, Ricinus communis, Rosa moschata, & Sambucus wightiana, Skimmia laureola, Solanum virginianum, Stellaria media, Viburnum \\
grandiflorum, Zanthoxylum armatum
\end{tabular}

Dermatological and topical diseases

Respiratory illness

Skeleto-muscular problems

Cardio-vascular complaints and circulatory diseases

Fever, headache, analgesic

Urinary complaints

Dental problems

ENT complaints

Nerve disorders (anodyne, epilepsy, sedative)

Genital and sexual diseases

Others (wounds, cuts, narcotic, tonic, tumor, anticancer and stimulant)
Abelmoschus esculentus, Allium cepa, Allium sativum, Amaranthus viridis, Brassica campestris, Celtis australis, Convolvulus arvensis, Cuscuta reflexa, Cynodon dactylon, Datura stramonium, Debregeasia saeneb, Echinops echinatus, Euphorbia wallichii, Indigofera heterantha, Jasminum officinale, Juglans regia, Melia azedarach, Onosma hispida, Periploca aphylla, Pistacia chinensis, Plantago lanceolata, Plantago major, Salvia lanata, Sambucus wightiana, Silene vulgaris, Skimmia laureola, Solanum nigrum

Abelmoschus esculentus, Allium cepa, Allium sativum, Amaranthus viridis, Arisaema jacquemontii, Arenaria griffithii, Artemisia scoporia, Delphinium denudatum, Elaeagnus umbellata, Ficus palmata, Geranium wallichianum, Heracleum candicans, Melia azedarach, Morus alba, Papaver somniferum, Ricinus communis

Aesculus indica, Aconitum violaceum, Atropa acuminata, Colchicum luteum, Daphne mucronata, Lotus corniculatus, Paeonia emodi, Polygonatum verticillatum, Sambucus wightiana, Sarcococca saligna

Ajuga bracteosa, Allium sativum, Colchicum luteum, Cuscuta reflexa, Dioscorea deltoidea, Elaeagnus umbellata, Hedera nepalensis, Otostegia limbata, Pistacia chinensis, Podophyllum hexandrum, Portulaca oleracea, Taraxacum spec.

Cichorium intybus, Delphinium denundatum, Geranium wallichianum, Hypericum perforatum, Jasminum humile, Melia azedarach, Papaver somniferum, Solanum nigrum, Thymus linearis, Verbena officinalis, Xanthium strumarium, Zanthoxylum armatum

Abelmoschus esculentus, Allium cepa, Allium sativum, Capsella bursa-pastoris, Chenopodium album, Cuscuta reflexa, Foeniculum vulgare, Fragaria vesca, Hypericum perforatum, Portulaca oleracea, Quercus oblongata, Quercus floribunda, Solanum virginianum, Taraxacum spec.

Isodon rugosus, Juglans regia, Olea europaea, Origanum vulgare, Otostegia limbata, Rumex dentatus

Ajuga bracteosa, Artemisia scoporia, Corydalis stewartii, Origanum vulgare, Primula denticulata

Ajuga bracteosa, Cannabis sativa

Allium cepa, Allium sativum, Avena sativa, Celtis australis, Colchicum luteum, Geranium wallichianum, Lotus corniculatus, Polygonatum multiflorum, Polygonatum verticillatum, Quercus dilatata, Withania somnifera

Allium cepa, Allium sativum, Avena sativa, Berberis lycium, Bergenia stracheyi, Cannabis sativa, Capsella bursa-pastoris, Coriandrum sativum, Cynodon dactylon, Datura stramonium, Juglans regia, Lathyrus aphaca, Paeonia emodi, Papaver somniferum, Periploca aphylla, Prunus armeniaca, Salvia moorcroftiana, Taraxacum spec.

Spiraea spec.
Woodlands are the main source for non-synanthropic indifferent kinds of woodland, while only few occur in wetlands (4) and mountain grasslands (4). Mountain grassland medicinal plants known in the Miandam valley comprise Colchicum luteum, Corydalis stewartii, Nepeta cataria and Thymus linearis. Since Himalayan mountain floras are rich [45-47] and the local almost certainly contains more species of pharmaceutical value, we assume that the habitat is too remote and too difficult to access to be of much interest as a "medicinal plant hunting area" for the people in the Miandam valley. digenous medicinal plants. They comprise 21 woody plants (apart from the climber Hedera nepalensis, seven trees and thirteen shrubs), two short-lived and 24 perennial herbs. Almost half of the perennial herbs are dug to collect the stem base (Primula denticulata) or chiefly the rhizomes (Aconitum violaceum, Arisaema jacquemontii, Bergenia stracheyi, Delphinium denudatum, Dioscorea deltoidea, Paeonia emodi, Podophyllum hexandrum, Polygonatum multiflorum, Polygonatum verticillatum). Except the latter 
two, these species are range-restricted taxa of Himalayan or narrower distribution. Due to their biochemical components they are largely unpalatable for livestock, hence fairly resistant under the widespread practice of wood-pasture, but may be vulnerable to overcollecting for medicinal purposes, although so far only Aconitum violaceum is considered rare in the study area. A currently more serious threat to the ethno-medicinal plant wealth of the woodlands as well as to the social and economic basis of the rural population in northern Pakistan is excessive timber exploitation leading to deforestation and habitat destruction.

\section{Conclusion}

The Miandam valley in northern Pakistan is very rich in commercially and pharmaceutically important ethnomedicinal plant species. The locals, in particular traditional healers, have centuries-old knowledge regarding the uses of the plants, and the locals use these species in a traditional way for curing a wide spectrum of diseases. Few species were found to be vulnerable probably due to overcollection. Especially perennial woodland herbs with rhizomes are of conservation concern. The local inhabitants depend on plants for the treatment of diseases but not all are familiar with the proper collection, parts to be used, preservation and storage. In contrast, local traditional healers are familiar with proper collection and use of medicinal plants, and they should be involved in efforts of conservation and sustainable use of ethnomedicinal plant resources. In view of the outstanding importance and ecosystem services of woodlands and forests in northern Pakistan the currently widespread and uncontrolled deforestation is a serious threat both to ecological and social sustainability as well as to the long-term economic basis of the local population [19]. It is also a threat to the ethno-medicinal plant wealth. For purposes of plant conservation and to increase the locals' income we suggest to cultivate vulnerable woodland medicinal plants of commercial value in newly designed and locally administered self-government agroforestry systems. Due to the specific habitat demands of many woodland plant species better results may be obtained through well managed agroforestry systems than in ex-situ sites [48].

\section{Competing interests}

The authors declare that they have no competing interests.

\section{Authors' contributions}

NA carried out the field work, analyzed the data and drafted the manuscript. EB revised the whole manuscript and contributed to the editing and interpreting of the data. AR conceptualized and designed the study while WM helped in the initial drafting of the manuscript. All authors read and approved the final manuscript.

\section{Acknowledgements}

This research was funded by HEC (Higher Education Commission of Pakistan) under the Faculty Development Program of the Islamia College University Peshawar, Pakistan. We are indebted to all villagers, guides and informants who shared their knowledge with us.

\section{Author details}

${ }^{1}$ Department of Botany, Islamia College University, Peshawar 25000, Pakistan. 2 Department of Vegetation Analysis and Phytodiversity, Albrecht von Haller Institute of Plant Sciences, Georg August University, Göttingen 37073,

Germany. ${ }^{3}$ Centre of Plant Diversity, University of Peshawar, Peshawar 25000, Pakistan. ${ }^{4}$ Department of Botany, Kohat University of Science and Technology, Kohat 26000, Pakistan.

Received: 26 November 2012 Accepted: 8 April 2013

Published: 15 April 2013

\section{References}

1. Bako SP, Bakfur MJ, John I, Bala El: Ethnomedicinal and phytochemical profile of some savanna plant species in Nigeria. Int J Bot 2005, 1:147-150.

2. WHO: Traditional medicine, growing needs and potential. WHO Policy Perspectives on Medicines 2002, 2:1-6.

3. Shinwari ZK: Medicinal plants research in Pakistan. J Med Plants Res 2010, 4:161-176.

4. Abbasi AM, Khan MA, Ahmad M, Zafar M: Medicinal plant biodiversity of lesser Himalayas, Pakistan. New York, Dordrecht, Heidelberg, London: Springer; 2012

5. Sher Z, Khan Z, Hussain F: Ethnobotanical studies of some plants of Chagharzai Valley, District Buner, Pakistan. Pakistan J Bot 2011, 43:1445-1452.

6. Shinwari ZK, Rehman M, Watanabe T, Yoshikawa Y: Medicinal and aromatic plants of Pakistan. A pictorial guide. Kohat, PK: Kohat University of Science and Technology; 2006.

7. Hussain F, Shah SM, Sher H: Traditional resource evaluation of some plants of Mastuj, District Chitral, Pakistan. Pakistan J Bot 2007, 39:339-354.

8. Ibrar M, Hussain F, Amir S: Ethnobotanical studies on plant resources of Ranyal hills, District Shangla, Pakistan. Pakistan J Bot 2007, 39:329-337.

9. Khan SW, Khatoon S: Ethnobotanical studies of some useful herbs of Haramosh and Bugrote valleys in Gilgit, Northern areas of Pakistan. Pakistan J Bot 2008, 40:43-58.

10. Sher H, Hussain SK: Ecological survey and rapid vulnerability assessment of medicinal and aromatic plants of Miandam, Pakistan. Peshawar, PK: WWF PK; 2007.

11. Ali H, Qaiser M: The ethnobotany of Chitral Valley, Pakistan, with particular reference to medicinal plants. Pakistan J Bot 2009, 41:2009-2041.

12. Hamayun $M$, Khan SA, Sohn EY, Lee IJ: Folk medicinal knowledge and conservation status of some economically valued medicinal plants of District Swat, Pakistan. Lyonia 2006, 11:101-113.

13. Hussain F, Sher H, Ibrar M, Durrani MJ: Ethnomedicinal uses of plants of District Swat, Pakistan. Pakistan J Plant Sci 2005, 11:137-158.

14. Sher H, Hussain F: Ethnobotanical evaluation of some plant resources in Northern part of Pakistan. J Biotechnol 2009, 8:4066-4076.

15. Shinwari ZK, Gilani SS: Sustainable harvest of medicinal plants at Bulashba Nullah, Astore (Northern Pakistan). J Ethnopharmacol 2003, 84:289-298

16. Adnan SM, Khan A, Latif A, Shinwari ZA: Threats to the sustainability of ethno-medicinal uses in Northern Pakistan. A case study of Miandam valley, District Swat, NWFP, Pakistan. Lyonia 2006, 11:91-100.

17. Porter SC: Quaternary glacial record in Swat Kohistan, West Pakistan. Geol Soc Am Bull 1970, 81:1421-1446.

18. Rashid M: Resource management plan for Swat Forest Range of Swat Forest Division. Forest Management Center NWFP, Forest Department \& Intercooperation SDC: Government of Switzerland; 1999.

19. Rabbi F, Bauer S, Idalinya J: Contribution of forests to rural inequality reduction: present scope and future options for rural development and sustainable use of forests. Int J Sust Dev World 2010, 17:4-14.

20. Nüsser $M$, Dickoré WB: $A$ tangle in the triangle: vegetation map of the eastern Hindukush (Chitral, northern Pakistan). Erdkunde 2002, 56:37-59.

21. Eberhardt E, Dickoré WB, Miehe G: Vegetation map of the Batura Valley (Hunza Karakorum, North Pakistan). Erdkunde 2007, 61:93-112.

22. Nasir E, Ali SI: Flora of West Pakistan. No.1-131. Karachi, PK: University of Karachi; 1970-1979.

23. Nasir E, Ali Sl: Flora of Pakistan. No. 132-193. Karachi, PK: University of Karachi; 1980-2005.

24. Nasir E, Ali Sl: Flora of West Pakistan and Kashmir. Islamabad: Pakistan Agriculture Research Council; 1970-1995.

25. Ali SI, Qaiser M: Flora of Pakistan. Karachi, PK: University Press; 1993-2012. 
26. Abbasi AM, Khan MA, Ahmad M, Zafar M, Khan H, Muhammad N, Sultana S: Medicinal plants used for the treatment of jaundice and hepatitis based on socio-economic documentation. African J Biotechnol 2009, 8:1643-1650.

27. Adnan M, Hölscher D: Medicinal plant abundance in degraded and reforested sites in Northwest Pakistan. Mt Res Dev 2010, 30:25-32.

28. Ali H, Sannai J, Sher H, Rashid A: Ethnobotanical profile of some plant resources in Malam Jabba valley of Swat, Pakistan. J Med Plants Res 2011, 5:4676-4687.

29. Awan MR, Iqbal Z, Shah SM, Jamal Z, Jan G, Afzal M, Majid A, Gul A: Studies on traditional knowledge of economically important plants of Kaghan Valley, Mansehra District, Pakistan. J Med Plants Res 2011, 5:3958-3967.

30. Badshah L, Hussain F: People preferences and use of local medicinal flora in District Tank, Pakistan. J Med Plants Res 2011, 5:22-29.

31. Hazrat A, Shah J, Ahmad S, Nisar M, Jan AK, Sikandar: Medicinal plants of Usherai Valley, Dir, NWFP, Pakistan. Pakistan J Bot 2010, 42:31-34.

32. Iqbal H, Sher Z, Khan Z: Medicinal plants from salt range, Pind Dadan Khan, District Jhelum, Punjab, Pakistan. J Med Plants Res 2011, 5:2157-2168.

33. Jabeen A, Khan MA, Ahmad M, Zafar M, Ahmad F: Indigenous uses of economically important flora of Margallah Hills National Park, Islamabad, Pakistan. Afr J Biotechnol 2009, 8:763-784.

34. Jan G, Khan MA, Farhatullah, Jan FG, Ahmad M, Jan M, Zafar M: Ethnobotanical studies on some useful plants of Dir Kohistan valleys, KPK, Pakistan. Pakistan J Bot 2011, 43:1849-1852.

35. Khan M, Musharaf S, Shinwari ZK: Ethnobotanical importance of halophytes of Noshpho salts mine, District Karak, Pakistan. Res Pharmaceut Biotechnol 2011, 3:46-52.

36. Mahmood A, Qureshi RA, Mahmood A, Sangi Y, Shaheen H, Ahmad I, Nawaz Z: Ethnobotanical survey of common medicinal plants used by people of District Mirpur, AJK, Pakistan. J Med Plants Res 2011, 5:4493-4498.

37. Razaq A, Rashid A, Ali H, Ahmad H, Islam M: Ethnomedicinal potential of plants of Changa Valley District, Shangla, Pakistan. Pakistan J Bot 2010, 42:3463-3475.

38. Pieroni A, Sheikh QZ, Ali W, Torry B: Traditional medicines used by Pakistani migrants from Mirpur living in Bradford, northern England. Complement Ther Med 2008, 16(2):81-86.

39. Teklehaymanot T, Giday M: Ethnobotanical study of medicinal plants used by people in Zegie Peninsula, Northwestern Ethiopia. J Ethnobiol Ethnomed 2007, 3:12-21.

40. Yineger $\mathrm{H}$, Kelbessa $\mathrm{E}$, Bekele $\mathrm{T}$, Lulekai E: Plants used in traditional management of human ailments at Bale Mountains National Park, South eastern Ethiopia. J Med Plants Res 2008, 2:132-153.

41. Okello J, Ssegawa P: Medicinal plants used by communities of Ngai Subcounty, Apac District, northern Uganda. Afr J Ecol 2007, 45:76-83.

42. Kala CP: Ethnomedicinal botany of the Apatani in the eastern Himalayan region of India. J Ethnobiol Ethnomed 2005, 1:11-18.

43. Muthu C, Ayyanar M, Raja N, Ignacimuthu S: Medicinal plants used by traditional healers in Kancheepuram District of Tamil Nadu, India. $J$ Ethnobiol Ethnomed 2006, 2:43-53.

44. Murad W, Ahmad A, Gilani SA, Khan MA: Indigenous knowledge and folk use of medicinal plants by the tribal communities of Hazar Nao Forest. J Med Plants Res 2011, 5:1072-1086.

45. Adnan M, Begum S, Khan AL, Tareen AM, Lee I-J: Medicinal plants and their uses in selected temperate zones of Pakistani Hindukush-Himalaya. J Med Plants Res 2012, 6:4113-4127.

46. Bhat JA, Kumar M, Bussmann RW: Ecological status and traditional knowledge of medicinal plants in Kedarnath Wildlife Sanctuary of Garhwal Himalaya India. J Ethnobiol Ethnomed 2013, 9:1.

47. Khan SM, Page S, Ahmad H, Shaheen H, Ullah Z, Ahmad M, Harper DM: Medicinal flora and ethnoecological knowledge in the Naran Valley, Western Himalaya, Pakistan. J Ethnobiol Ethnomed 2013, 9:4.

48. Sher $\mathrm{H}$, Hussain $\mathrm{F}$, Sher $\mathrm{H}$ : Ex-situ management study of some high value medicinal plant species in Swat, Pakistan. Ethnobot Res Appl 2010, 8:17-24.

doi:10.1186/1746-4269-9-25

Cite this article as: Akhtar et al:: Diversity and use of ethno-medicinal plants in the region of Swat, North Pakistan. Journal of Ethnobiology and Ethnomedicine 2013 9:25.

\section{Submit your next manuscript to BioMed Central and take full advantage of:}

- Convenient online submission

- Thorough peer review

- No space constraints or color figure charges

- Immediate publication on acceptance

- Inclusion in PubMed, CAS, Scopus and Google Scholar

- Research which is freely available for redistribution

Submit your manuscript at www.biomedcentral.com/submit
C Biomed Central 